\title{
Sulphur Dynamics under different land uses of Outer Himalayan region of Himachal Pradesh
}

\author{
Deepika Suri \\ Department of Soil Science, Chaudhary Sarvan Kumar Himachal Pradesh Krishi Vishvavidyalaya, Palampur, Himachal Pradesh \\ V. K. Sharma \\ Department of Soil Science, Chaudhary Sarvan Kumar Himachal Pradesh Krishi Vishvavidyalaya, Palampur, Himachal Pradesh \\ Pardeep Kumar \\ Department of Soil Science, Chaudhary Sarvan Kumar Himachal Pradesh Krishi Vishvavidyalaya, Palampur, Himachal Pradesh \\ R.G. Upadhayay \\ Department of Biology and Environmental Sciences, Chaudhary Sarvan Kumar Himachal Pradesh Krishi Vishvavidyalaya, \\ Palampur, Himachal Pradesh \\ Gazala Nazir \\ Department of Soil Science, Punjan Agricultural University, Ludhiana, Punjab \\ Anjali 鴈 \\ Department of Soil Science, Chaudhary Sarvan Kumar Himachal Pradesh Krishi Vishvavidyalaya, Palampur, Himachal Pradesh
}

\begin{tabular}{|c|c|}
\hline ARTICLE INFO & ABSTRACT \\
\hline $\begin{array}{l}\text { Received : } 24 \text { September } 2021 \\
\text { Revised : } 15 \text { November } 2021 \\
\text { Accepted : } 22 \text { November } 2021 \\
\text { Available online: } 19 \text { December } 2021 \\
\text { Key Words: } \\
\text { Exchangeable Sulphur } \\
\text { Non-sulphate Sulphur } \\
\text { Organic Sulphur } \\
\text { Total Sulphur } \\
\text { Water soluble sulphur }\end{array}$ & $\begin{array}{l}\text { The knowledge of different sulphur (S) forms and their relationship with soil } \\
\text { properties is of much relevance in assessing the short- and long-term } \\
\text { availability of the nutrients to crops and in formulating sound fertilizer } \\
\text { recommendations. For this purpose one hundred and one representative soil } \\
\text { samples were collected from the study area and analyzed for various } \\
\text { physicochemical properties and forms of sulphur (water soluble, exchangeable, } \\
\text { available, organic, non-sulphate and total } S \text { ) using standard methods. The } \\
\text { different forms of sulphur viz., water soluble, exchangeable, available, organic, } \\
\text { non-sulphate and total sulphur ranged from } 1.1 \text { to } 7.0,1.9 \text { to } 10.9,3.1 \text { to } 21.1 \text {, } \\
75.9 \text { to } 316.1,8.0 \text { to } 41.5 \text { and } 75.5 \text { to } 372.5 \text { mg } \mathrm{kg}^{-1} \text {, respectively in soils of Outer } \\
\text { Himalayas under different land uses. The content of different forms of sulphur } \\
\text { present in these soils were in the order of total sulphur, organic sulphur, non- } \\
\text { sulphate sulphur, available sulphur, exchangeable sulphur and water soluble } \\
\text { sulphur. All the forms of } S \text { correlated positively and significantly with organic } \\
\text { carbon and clay content of soils. A negative and significant relationship was } \\
\text { also observed between all forms of sulphur and sand content of soils. In the } \\
\text { present study, it was also found that all forms of } S \text { present in soils were } \\
\text { significantly and positively correlated with each other. The knowledge } \\
\text { regarding different forms of } S \text { in soils and their availability controlled by } \\
\text { different soil properties will be helpful for its management to optimize crop } \\
\text { yields in the Outer Himalayas of Himachal Pradesh. }\end{array}$ \\
\hline
\end{tabular}

\section{Introduction}

Sulphur is one of the 17 mineral nutrients which are essential for the growth and development of plants. Sulphur is also essential for human and animals and is increasingly being recognized as the fourth major plant nutrient after nitrogen, phosphorus and potassium. Sulphate sulphur is the most abundant form of inorganic sulphur found in most of the soils and it is the form that the plants generally take up, although other reduced forms, such as elemental sulphur, thiosulphate and sulphide are important for anaerobic soils (Zhou et al., 2005). However, the bulk of soil sulphur in natural and managed ecosystems is in organic form, which is directly affected by microbial activity through decomposition processes (Solomon et al., 2001). The occurrence of sulphur deficiencies in Indian

Corresponding author E-mail: anjalidhiman214@gmail.com

Doi: https://doi.org/10.36953/ECJ.2021.22331

This work is licensed under Attribution-Non Commercial 4.0 International (CC BY-NC 4.0)

(C) ASEA 
soils has increased manifolds with increasing use of high analysis fertilizers with low sulphur content, and greater crop removal of the nutrient from the ever increasing multiple cropping systems. Based on the recent Indian Council of Agricultural Research (ICAR) report, out of total soil samples analyzed across 20 states, on an average 33 percent of samples were deficient in sulphur. Sulphur exists in different forms, the knowledge of these forms of sulphur in soils together with their distribution in the root zone is of much relevance in assessing the sulphur supplying capacity of the soils (Azmi et al., 2018). The nature and amount of various forms of sulphur depends on variation in soil texture, $\mathrm{pH}$, calcium carbonate, organic matter and many other soil physical and chemical characteristics (Zho Hua-Yun et al., 2015). The availability of sulphur in a soil is not only influenced by management practices but also depends upon various forms of sulphur present as these different forms of sulphur exist in dynamic equilibrium in soil (Azmi et al., 2018). Major agricultural land of Outer Himalayas is under maize-wheat sequence, paddy-wheat sequence, vegetable based cropping sequences, sugarcane based cropping sequences and orchards. These crops are cultivated without addition of sulphur fertilizers. Since no systematic information is available regarding distribution of sulphur forms in these agriculturally important soils of the Outer Himalayas of Himachal Pradesh, the present study was undertaken to assess the status of different forms of sulphur and delineate the area of deficiency or sufficiency of sulphur.

\section{Material and Methods \\ Description of study area}

Himachal Pradesh is situated between $30^{\circ} 23^{\prime} 40^{\prime \prime} \mathrm{N}$ to $33^{\circ} 12^{\prime} 40^{\prime \prime} \mathrm{N}$ latitudes and $75^{\circ} 45^{\prime} 55^{\prime \prime} \mathrm{E}$ to $79^{\circ} 04^{\prime} 20^{\prime \prime}$ E longitudes with an area of 55, $673 \mathrm{sq}$ km. The Outer Himalayas of Himachal Pradesh (popularly known as the shivalik hills) covers an area of 9.13 lakh ha at an altitude ranging from 350 to $650 \mathrm{~m}$ above mean sea level in Una, Bilaspur, Hamirpur, Sirmaur, Kangra and Solan districts of Himachal Pradesh. Five land uses were chosen for this study and these were Maize-Wheat, PaddyWheat, vegetable based cropping sequences, sugarcane based cropping sequences and orchard belonging to the soil orders Inceptisol and Entisol. The annual rainfall of the area is around $1100 \mathrm{~mm}$ and the prevailing temperature lies between $15{ }^{\circ} \mathrm{C}$ to $23{ }^{\circ} \mathrm{C}$.

\section{Location and procedure of soil sampling}

A total of 101 soil samples were collected from the cultivated areas of Una, Bilaspur, Hamirpur, Sirmaur, Kangra and Solan districts of Himachal Pradesh (Figure 1). Out of these one hundred and one sites $38,15,18,15$ and 15 sites represent the soils under maize-wheat, paddy-wheat, vegetables, sugarcane and fruit trees, respectively. Land use sites for taking soil samples were selected on the basis of cropping pattern followed and cultivation history. Representative sampling sites were selected randomly from each land use. Three representative units were selected from each land use and from each unit composite soil samples were collected from ten soil subsamples (points). Soil samples from 0 to $15 \mathrm{~cm}$ and 15 to $30 \mathrm{~cm}$ depth for the agricultural lands under field crops and established orchards/ plantations, respectively were collected randomly using stainless steel soil augers and taken to the laboratory for analysis. The latitude, longitude and mean sea level of the sampling sites were recorded using a handheld global positioning system. Collected soil samples were air dried, ground to pass a 2-mm sieve after stone and debris were removed, and then stored in plastic bottles for analysis in laboratory

\section{Soil analysis}

The processed soil samples were analyzed for important soil properties viz., $\mathrm{pH}$, electrical conductivity (EC), organic carbon (OC), mechanical separates, cation exchange capacity (CEC), base saturation (BS) \& calcium carbonate content $\left(\mathrm{CaCO}_{3}\right)$ and available nutrient status using standard methods (Piper 1966; Jackson 1977). Total and organic-S were determined as per methods outlined by Chapman and Pratt 1961 arid Bradsley and Lancaster (1965), respectively. Available S was extracted with $0.15 \%$ $\mathrm{CaCl}_{2}$ (Williams and Steinbergs 1959). Sulphur in all the extracts was determined by the turbidimetric procedure of Chesnin and Yien (1951). The difference between organic $S$ plus available $S$ contents and total $\mathrm{S}$ was denoted as non-sulphate $\mathrm{S}$.

\section{Results and Discussion}

\section{Physicochemical properties}

The results showed that sand (\%), silt (\%), clay (\%), textural class, soil $\left.\mathrm{pH}(1: 2.5), \mathrm{EC}(\mu \mathrm{S} \mathrm{cm})^{-1}\right), \mathrm{OC}(\mathrm{g}$ $\left.\mathrm{kg}^{-1}\right), \mathrm{CEC}\left\{\mathrm{cmol}(\mathrm{p}+) \mathrm{kg}^{-1}\right\}$, BS $(\%)$ and $\mathrm{CaCO}_{3}(\%)$ in these soils varied from 40 to 80,12 
Table 1: Physical and chemical properties of soils under different land uses.

\begin{tabular}{|c|c|c|c|c|c|c|c|c|c|c|}
\hline \multirow{2}{*}{$\begin{array}{l}\text { Cropping } \\
\text { sequence }\end{array}$} & \multicolumn{4}{|c|}{ Soil texture } & \multirow{2}{*}{$\begin{array}{l}\mathrm{pH} \\
(1: 2.5)\end{array}$} & \multirow{2}{*}{$\begin{array}{l}\text { EC } \\
\left(\mu S \mathrm{~cm}^{-1}\right)\end{array}$} & \multirow{2}{*}{$\begin{array}{l}\mathrm{OC} \\
\left(\mathrm{g} \mathrm{kg}^{-1}\right)\end{array}$} & \multirow{2}{*}{$\begin{array}{l}\text { CEC } \\
\{\mathrm{cmol} \\
\left.\left(\mathrm{p}^{+}\right) \mathrm{kg}^{-}\right\}\end{array}$} & \multirow{2}{*}{$\begin{array}{l}\text { BS } \\
(\%)\end{array}$} & \multirow{2}{*}{$\begin{array}{l}\mathrm{CaCO}_{3} \\
(\%)\end{array}$} \\
\hline & $\begin{array}{l}\text { Sand } \\
(\%)\end{array}$ & $\begin{array}{l}\text { Silt } \\
(\%)\end{array}$ & $\begin{array}{l}\text { Clay } \\
(\%)\end{array}$ & Class & & & & & & \\
\hline Maize-wheat & $\begin{array}{l}40-79 \\
(58)\end{array}$ & $\begin{array}{l}12-45 \\
(27)\end{array}$ & $\begin{array}{l}6-24 \\
(14)\end{array}$ & sl-scl & $\begin{array}{l}6.1-7.3 \\
(6.8)\end{array}$ & $\begin{array}{l}153-270 \\
(187)\end{array}$ & $\begin{array}{l}3.1-15.3 \\
(6.6)\end{array}$ & $\begin{array}{l}4.9-13.3 \\
(8.1)\end{array}$ & $\begin{array}{l}60-76 \\
(68)\end{array}$ & $\begin{array}{l}0.05-0.45 \\
(0.24)\end{array}$ \\
\hline Paddy-wheat & $\begin{array}{l}47-66 \\
(57)\end{array}$ & $\begin{array}{l}23-25 \\
(29)\end{array}$ & $\begin{array}{l}10-18 \\
(14)\end{array}$ & sl-1 & $\begin{array}{l}6.5-7.6 \\
(7.0)\end{array}$ & $\begin{array}{l}143-287 \\
(208)\end{array}$ & $\begin{array}{l}3.8-9.9 \\
(7.4)\end{array}$ & $\begin{array}{l}6.1-10.4 \\
(8.0)\end{array}$ & $\begin{array}{l}62-77 \\
(69)\end{array}$ & $\begin{array}{l}0.40-1.95 \\
(0.95)\end{array}$ \\
\hline $\begin{array}{l}\text { Vegetable } \\
\text { based } \\
\text { cropping } \\
\text { sequences }\end{array}$ & $\begin{array}{l}47-80 \\
(61)\end{array}$ & $\begin{array}{l}12-35 \\
(26)\end{array}$ & $\begin{array}{l}7-21 \\
(13)\end{array}$ & ls-scl & $\begin{array}{l}6.1-7.6 \\
(7.0)\end{array}$ & $\begin{array}{l}145-372 \\
(240)\end{array}$ & $\begin{array}{l}3.6-11.7 \\
(6.9)\end{array}$ & $\begin{array}{l}4.8-11.2 \\
(7.6)\end{array}$ & $\begin{array}{l}61-74 \\
(68)\end{array}$ & $\begin{array}{l}0.28-1.30 \\
(0.60)\end{array}$ \\
\hline $\begin{array}{l}\text { Sugarcane } \\
\text { based } \\
\text { cropping } \\
\text { sequences }\end{array}$ & $\begin{array}{l}53-74 \\
(62)\end{array}$ & $\begin{array}{l}19-32 \\
(25)\end{array}$ & $\begin{array}{l}7-15 \\
(13)\end{array}$ & sl & $\begin{array}{l}6.7-7.8 \\
(7.2)\end{array}$ & $\begin{array}{l}175-318 \\
(232)\end{array}$ & $\begin{array}{l}4.5-9.1 \\
(6.2)\end{array}$ & $\begin{array}{l}4.8-8.0 \\
(6.9)\end{array}$ & $\begin{array}{l}67-75 \\
(71)\end{array}$ & $\begin{array}{l}1.00-2.20 \\
(1.84)\end{array}$ \\
\hline Orchards & $\begin{array}{l}40-76 \\
(59)\end{array}$ & $\begin{array}{l}15-36 \\
(27)\end{array}$ & $\begin{array}{l}7-24 \\
(14)\end{array}$ & sl-1 & $\begin{array}{l}6.3-7.3 \\
(6.9)\end{array}$ & $\begin{array}{l}142-229 \\
(181)\end{array}$ & $\begin{array}{l}3.7-9.9 \\
(6.4)\end{array}$ & $\begin{array}{l}4.7-12.6 \\
(7.6)\end{array}$ & $\begin{array}{l}61-76 \\
(68)\end{array}$ & $\begin{array}{l}0.20-0.30 \\
(0.24)\end{array}$ \\
\hline
\end{tabular}

Note: $s$ l=sandy loam, l=loam, ls=loamy sand, $\mathbf{s c l =}=$ sandy clay loam

Values in parenparenthesis " $(0$ )" indicates mean

Table 2: Distribution of $S$ fractions in soils under different land uses

\begin{tabular}{|c|c|c|c|c|c|c|}
\hline \multirow[t]{3}{*}{ Cropping Sequence } & \multicolumn{6}{|c|}{ Sulphur forms } \\
\hline & WS-S & Ex-S & Av-S & Org-S & NS-S & Total-S \\
\hline & \multicolumn{6}{|c|}{$\left(\mathrm{mg} \mathrm{kg}^{-1}\right)$} \\
\hline Maize-wheat & $\begin{array}{l}1.1-7.0 \\
(3.5)\end{array}$ & $\begin{array}{l}1.9-10.9 \\
(5.9)\end{array}$ & $\begin{array}{l}3.1-17.9 \\
(9.4)\end{array}$ & $\begin{array}{l}75.9-316.1 \\
(143.4)\end{array}$ & $\begin{array}{l}8.0-40.5 \\
(22.6)\end{array}$ & $\begin{array}{l}92.3-372.5 \\
(175.4)\end{array}$ \\
\hline Paddy-wheat & $\begin{array}{l}1.8-5.8 \\
(4.1)\end{array}$ & $\begin{array}{l}2.7-10.3 \\
(6.8)\end{array}$ & $\begin{array}{l}4.5-16.0 \\
(10.9)\end{array}$ & $\begin{array}{l}99.5-204.3 \\
(157.3)\end{array}$ & $\begin{array}{l}17.2-29.0 \\
(21.5)\end{array}$ & $\begin{array}{l}122.4-247.2 \\
(189.4)\end{array}$ \\
\hline $\begin{array}{l}\text { Vegetable based } \\
\text { cropping sequence }\end{array}$ & $\begin{array}{l}1.5-6.3 \\
(3.9) \\
\end{array}$ & $\begin{array}{l}2.5-10.4 \\
(6.4)\end{array}$ & $\begin{array}{l}4.0-16.5 \\
(10.8) \\
\end{array}$ & $\begin{array}{l}81.6-240.5 \\
(147.1)\end{array}$ & $\begin{array}{l}9.5-35.5 \\
(20.3) \\
\end{array}$ & $\begin{array}{l}96.5-281.9 \\
(177.7)\end{array}$ \\
\hline $\begin{array}{l}\text { Sugarcane based } \\
\text { cropping sequence }\end{array}$ & $\begin{array}{l}2.5-5.7 \\
(3.5)\end{array}$ & $\begin{array}{l}4.6-8.6 \\
(5.8)\end{array}$ & $\begin{array}{l}7.1-14.3 \\
(9.3)\end{array}$ & $\begin{array}{l}93.0-177.7 \\
(130.9)\end{array}$ & $\begin{array}{l}9.2-25.0 \\
(19.6)\end{array}$ & $\begin{array}{l}110.2-215.0 \\
(159.9)\end{array}$ \\
\hline Orchards & $\begin{array}{l}1.7-5.7 \\
(3.5) \\
\end{array}$ & $\begin{array}{l}2.7-9.0 \\
(5.7) \\
\end{array}$ & $\begin{array}{l}4.5-14.7 \\
(9.2) \\
\end{array}$ & $\begin{array}{l}84.5-208.7 \\
(137.7) \\
\end{array}$ & $\begin{array}{l}9.8-41.5 \\
(23.1) \\
\end{array}$ & $\begin{array}{l}106.0-255.3 \\
(170)\end{array}$ \\
\hline
\end{tabular}

Note: WS=Water soluble, $\mathbf{E x}=$ Exchangeable, $A v=$ Available, Org=Organic, $\mathbf{N S}=$ Non sulphate

Values in parenparenthesis " () " indicates mean

to 45,6 to 24 , loamy sand to sandy clay loam, 6.1 respectively (Figure 2). Water soluble $\mathrm{S}$ exhibited a to 7.8 (slightly acidic to slightly alkaline), 142 to significant positive correlation with organic carbon $372,3.1$ to $15.3,4.7$ to $13.3,60$ to 77 and 0.05 to $\left(\mathrm{r}=0.80^{*}\right), \mathrm{CEC}\left(\mathrm{r}=0.71^{*}\right)$ and clay $\left(\mathrm{r}=0.74^{*}\right)$ and 2.20 with respective mean values of 59, 27, 14, 7.0, significant negative with sand $(\mathrm{r}=-0.22 *)$ (Table 3 ). 205, 6.7, 7.8, 69 and 0.70 in cultivated soils of The amount of water soluble sulphur in soils of the Outer Himalayas of Himachal Pradesh region study area is comparable with that reported by (Table 1).

\section{Distribution of sulphur forms}

Water soluble sulphur

Bandyopadhyay and Chattopadhyay (2001) and Majumdar and Patil (2017).

The water soluble sulphur content in these soils Exchangeable sulphur in these soils ranged from ranged from 1.1 to $7.0 \mathrm{mg} \mathrm{kg}^{-1}$ with mean value of 1.9 to $10.9 \mathrm{mg} \mathrm{kg}^{-1}$ with mean value of $6.1 \mathrm{mg} \mathrm{kg}^{-1}$. $3.7 \mathrm{mg} \mathrm{kg}^{-1}$. On an average, it constituted 1.99, On an average, it constituted 3.36, 3.59, 3.60, 3.63 $2.16,2.19,2.19$ and 2.06 per cent of total $\mathrm{S}$ in soils and 3.35 per cent of total $\mathrm{S}$ in soils under maizeunder maize-wheat sequence, paddy-wheat wheat sequence, paddy-wheat sequence, vegetable sequence, vegetable based cropping sequences, based cropping sequences, sugarcane based sugarcane based cropping sequences and orchards, cropping sequences and orchards, respectively 
Table 3: Simple correlation coefficients between sulphur forms and soil properties.

\begin{tabular}{|l|c|c|c|c|c|c|c|c|c|}
\hline \multirow{2}{*}{$\begin{array}{l}\text { Sulphur } \\
\text { Forms }\end{array}$} & Sand & Silt & Clay & pH & EC & OC & CEC & BS & CaCO $_{3}$ \\
\hline WS-S & $-0.22^{*}$ & 0.18 & $0.74^{*}$ & -0.10 & -0.10 & $0.80^{*}$ & $0.71^{*}$ & -0.14 & -0.26 \\
\hline Ex-S & $-0.21^{*}$ & 0.19 & $0.84^{*}$ & -0.18 & -0.12 & $0.84^{*}$ & $0.70^{*}$ & -0.15 & -0.28 \\
\hline Av-S & $-0.22^{*}$ & 0.19 & $0.80^{*}$ & -0.08 & -0.10 & $0.80^{*}$ & $0.70^{*}$ & -0.11 & -0.27 \\
\hline Org-S & $-0.21^{*}$ & 0.17 & $0.68^{*}$ & -0.15 & -0.14 & $0.79^{*}$ & $0.68^{*}$ & -0.16 & -0.28 \\
\hline NS-S & $-0.24^{*}$ & 0.17 & $0.72^{*}$ & -0.12 & -0.05 & $0.46^{*}$ & $0.58^{*}$ & -0.05 & -0.19 \\
\hline Total-S & $-0.25^{*}$ & 0.19 & $0.64^{*}$ & -0.09 & 0.02 & $0.80^{*}$ & $0.68^{*}$ & -0.08 & -0.18 \\
\hline
\end{tabular}

*Significant at 5 per cent level of significance

Note: $W S=W a t e r$ soluble, $\mathbf{E x}=$ Exchangeable, $A v=$ Available, Org=Organic, $\mathbf{N S}=$ Non sulphate

Table 4: Simple correlation coefficients between Sulphur forms

\begin{tabular}{|l|l|l|l|l|l|l|}
\hline S Forms & WS-S & Ex-S & Av-S & Org-S & NS-S & Total-S \\
\hline WS-S & - & & & & & \\
\hline Ex-S & $0.78^{*}$ & - & & & & \\
\hline Av-S & $0.76^{*}$ & $0.78^{*}$ & - & & & \\
\hline Org-S & $0.61^{*}$ & $0.62^{*}$ & $0.59^{*}$ & - & & \\
\hline NS-S & $0.51^{*}$ & $0.51^{*}$ & $0.55^{*}$ & $0.48^{*}$ & - & \\
\hline Total-S & $0.55^{*}$ & $0.59^{*}$ & $0.60^{*}$ & $0.81^{*}$ & $0.49^{*}$ & - \\
\hline
\end{tabular}

*Significant at 5 per cent level of significance

Note: WS=Water soluble, $\mathbf{E x}=$ Exchangeable, $A v=$ Available, Org=Organic, $\mathbf{N S}=$ Non sulphate

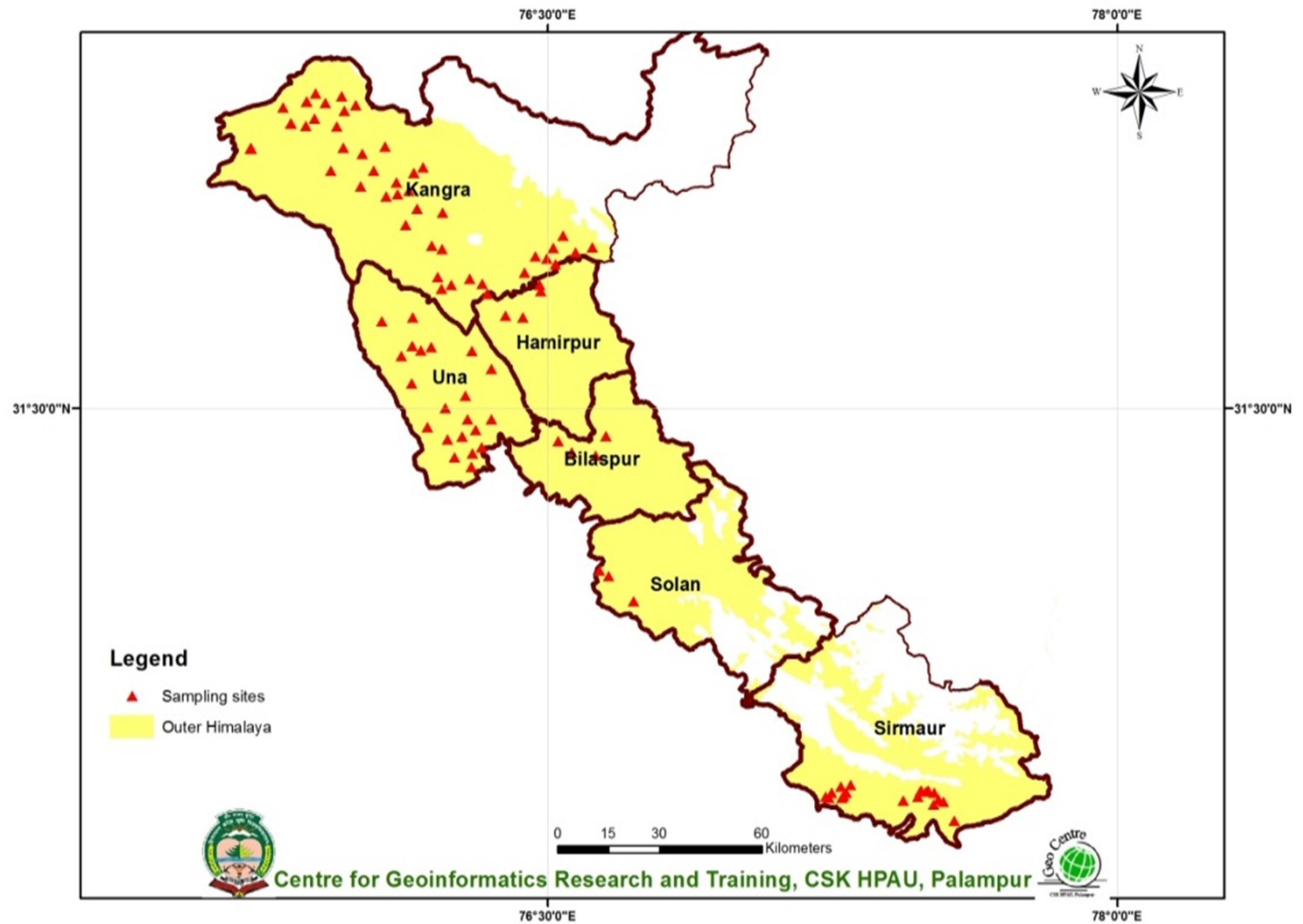

Figure 1: Location of soil sampling sites in Outer Himalayan region of Himachal. 


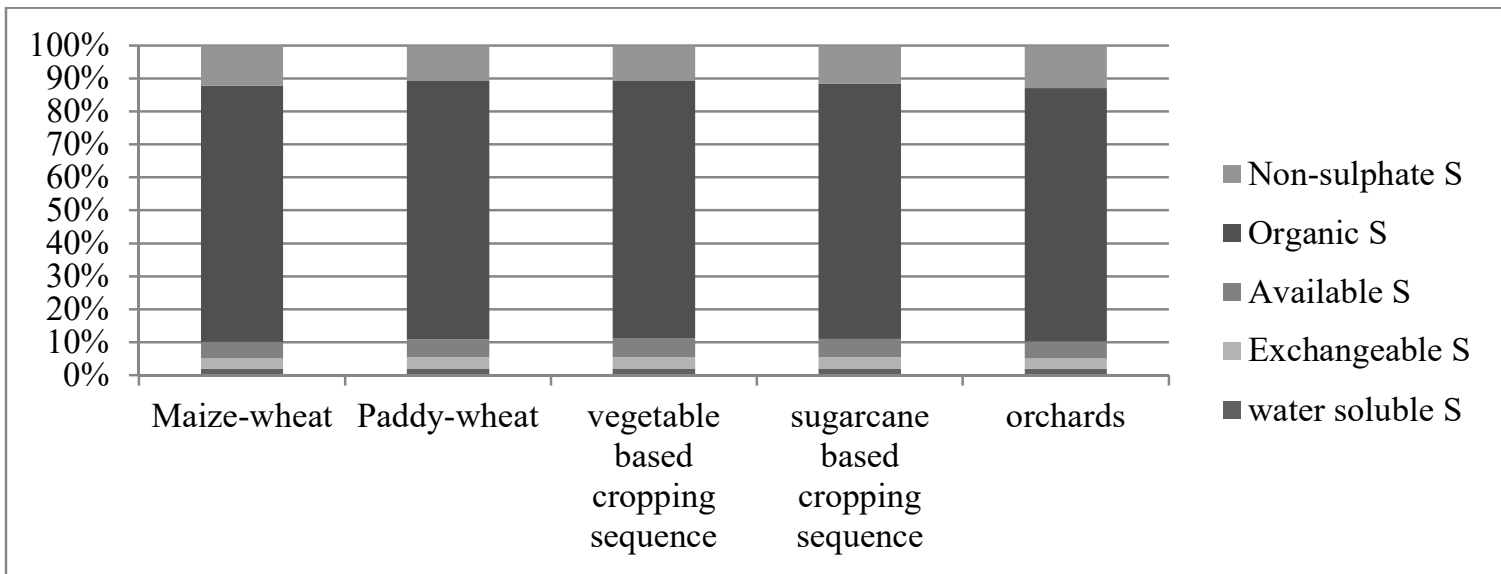

Figure 2: Per cent contribution of different forms of $S$ to total $S$ in soils under different land uses

(Figure 2). Exchangeable sulphur exhibited a significant positive correlation with organic carbon $\left(\mathrm{r}=0.84^{*}\right)$, CEC $\left(\mathrm{r}=0.70^{*}\right)$ and clay $\left(\mathrm{r}=0.84^{*}\right)$ and significant negative with sand $\left(\mathrm{r}=-0.21^{*}\right)$ (Table 3$)$. The content of exchangeable sulphur was in agreement with that reported by Khalid et al., (2011) in soils of Pakistan and Anjali and Das (2012) in some soils of plain zone of Assam.

\section{Available sulphur}

Available sulphur in these soils ranged from 3.1 to $21.1 \mathrm{mg} \mathrm{kg}^{-1}$ with mean value of $9.8 \mathrm{mg} \mathrm{kg}^{-1}$. On an average, it constituted 5.36, 5.75, 6.08, 5.81 and 5.41 per cent of total $\mathrm{S}$ in soils under maize-wheat sequence, paddy-wheat sequence, vegetable based cropping sequences, sugarcane based cropping sequences and orchards, respectively (Figure 2). Available $\mathrm{S}$ exhibited a significant positive correlation with organic carbon $\left(\mathrm{r}=0.80^{*}\right)$, CEC $\left(\mathrm{r}=0.70^{*}\right)$ and clay $\left(\mathrm{r}=0.80^{*}\right)$ and significant negative with sand $(\mathrm{r}=-0.22 *)$ (Table 3$)$. The content of available sulphur was in line with that reported by Dhamak et al. (2014) and Majumdar and Patil (2016).

\section{Organic sulphur}

Organic sulphur content in these soils varied from 75.9 to $316.1 \mathrm{mg} \mathrm{kg}^{-1}$ with the mean value of 143.4 $\mathrm{mg} \mathrm{kg}^{-1}$. On an average, it constituted 81.76, 83.05, $82.78,81.86$ and 81 per cent of total $\mathrm{S}$ in soils under maize-wheat sequence, paddy-wheat sequence, vegetable based cropping sequences, sugarcane based cropping sequences and orchards, respectively (Figure 2). On an average, it constituted 82.56 per cent of total $\mathrm{S}$ in soils (Table
2). Organic $S$ exhibited a significant positive correlation with organic carbon $\left(\mathrm{r}=0.79^{*}\right)$, CEC $(r=0.68)$ and clay $\left(r=0.68^{*}\right)$ and significant negative with sand $\left(\mathrm{r}=-0.21^{*}\right) \quad$ (Table 3). Similar observations were reported by Patra et al., (2012) in different blocks of four districts of West Bengal and Sutaria et al. (2016) in soils of Rajkot District of Gujarat.

\section{Non-sulphate sulphur}

Non-sulphate sulphur content in these soils varied from 8.0 to $41.5 \mathrm{mg} \mathrm{kg}^{-1}$ with the mean value of $21.7 \mathrm{mg} \mathrm{kg}^{-1}$. On an average, it constituted 12.88 , $11.35,11.42,12.26$ and 13.59 per cent of total $\mathrm{S}$ in soils under maize-wheat sequence, paddy-wheat sequence, vegetable based cropping sequences, sugarcane based cropping sequences and orchards, respectively (Figure 2). On an average, it constituted 12.03 per cent of total sulphur in soils (Table 2). Non-sulphate $\mathrm{S}$ exhibited a significant positive correlation with organic carbon $\left(\mathrm{r}=0.46^{*}\right)$, $\mathrm{CEC}\left(\mathrm{r}=0.58^{*}\right)$ and clay $\left(\mathrm{r}=0.72^{*}\right)$ and significant negative with sand $(\mathrm{r}=-0.24 *)$ (Table 3$)$. These observations are in conformity with those of Swarnakar and Verma (1978) in Bundelkhand soils.

\section{Total sulphur}

The total sulphur content in these soils varied from 75.5 to $281.9 \mathrm{mg} \mathrm{kg}^{-1}$ with the mean value of 155.6 $\mathrm{mg} \mathrm{kg}^{-1}$ (Table 2). Total $\mathrm{S}$ exhibited a significant positive correlation with organic carbon $(\mathrm{r}=0.80 *)$, CEC $\left(r=0.68^{*}\right)$ and clay $\left(r=0.64^{*}\right)$ and significant negative with sand $\left(\mathrm{r}=-0.25^{*}\right)$ (Table 3$)$. Similar findings have been reported by Dolui and Guhathakurta (2007) in soils from different agro- 
climatic region of West Bengal and Bhogal et al., (1996) in soils of Muzaffarpur and Samastipur districts of Bihar. It may be inferred from previously mentioned results that amount of $S$ in each of its chemical pools differs within and between soils. Water-soluble and exchangeable sulphur is directly available to plants, while the mineralization of sulphate from organic sulphur also made an important contribution to plant uptake of sulphur. The forms of sulphur present in these soils are in the order of total S, organic S, nonsulphate $\mathrm{S}$, available $\mathrm{S}$, exchangeable $\mathrm{S}$ and water soluble S. The distribution of $\mathrm{S}$ forms in cultivated soils can be explained on basis of variation in soil properties affecting their content, soil mineralogy, soil weathering stage and dynamic equilibria

\section{References}

Azmi, N. Y. Seema, \& Manish, K., (2018). New technique for sequential fractionation of soil sulphur. International Journal of Current Microbiology and Appled Sciences, 7, 3397-3405.

Bandyopadhyay, P. K., \& Chattopadhyay, G. N. (2001). Different forms of sulphur in relation to soil properties in some Alfisols and Inceptisols of Birbhum district of West Bengal.

Anjali, B., \& Das, K. N. (2012). Forms of sulphur and their relationship with soil properties in some soils of North Bank Plain zone of Assam. Agropedology, 22(1), 43-49.

Bhogal, N. S., Choudhary, K. C., \& Sakal, R. (1996). Distribution of different forms of sulphur in Calciorthents of North Bihar. Journal of the Indian Society of Soil Science, 44(1), 65-69.

Chesnin, L., \& Yien, C. H. (1951). Turbidimetric determination of available sulfates. Soil Science Society of America Journal, 15(C), 149-151.

Dhamak, A. L., Meshram, N. A., \& Waikar, S. L. (2014). Comparative studies on dynamics soil properties and forms of sulphur in oilseed growing soils of Ambajogai Tahsil of Beed district. IOSR Journal of Agriculture and Veterinary Science, 7(12), 98-102.

Dolui, A. K., \& Pradhan, S. (2007). Sulphur mineralization and carbon, nitrogen, and sulphur relationships in some Alfisols of India. Communications in soil science and plant analysis, 38(1-2), 133-146.

Khalid, R., Khan, K. S., Akram, Z., Qureshi, R., \& Gulfraz, M. (2011). Relationship of plant available sulphur with soil between different forms. Organic $\mathrm{S}$ and nonsulphate S content constituted largest components of total S, mainly governed by organic carbon and clay content. It was found that all forms of $S$ present in soils were significantly and positively correlated with each other (Table 4).

\section{Conclusions}

Perusal of the data indicated that the abundance of various forms of sulphur in these low base saturated soils was in the order of total $\mathrm{S}>$ organic $\mathrm{S}>$ nonsulphate $\mathrm{S}>$ available $\mathrm{S}>$ exchangeable $\mathrm{S}>$ water soluble $\mathrm{S}$ and their availability was influenced by various soil properties. The results indicated that different forms of sulphur in these soils follow each other and are inter-related within them.

characteristics, rainfall and yield levels of oilseed crops in Pothwar Pakistan. Pakistan Journal of Botany, 43(6), 2929-2935.

Majumdar, S., \& Patil, P. L. (2017). Carbon dynamics under different land use systems of a micro-watershed in Northern Transition Zone of Karnataka. ORYZA-An International Journal on Rice, 54(4), 414-419.

Patra, P., Mondal, S., \& Ghosh, G. K. (2012). Distribution of sulphur fractions in surface and sub-surface soils of red and lateritic soils of West Bengal. Indian Agriculturist, 56(1/2), $1-7$.

Solomon, D., Lehmann, J., Tekalign, M., Fritzsche, F., \& Zech, W. (2001). Sulfur fractions in particle-size separates of the sub-humid Ethiopian highlands as influenced by land use changes. Geoderma, 102(1-2), 41-59.

Sutaria, G. S., Vora, V. D., Talpada, M. M., Hirpara, D. S., Vekaria, P. D., \& Akbari, K. N. (2016). Studies on sulphur fractions in soils of Rajkot district, Gujarat. International Journal of Agricultural Science and Research, 6(1), 61-68.

Swarnkar, K. C., \& Verma, M. M. (1978). Distribution of forms of sulphur in soil profiles of Bundel Khand region [India]. Indian Journal of Agricultural Chemistry.

Zho Hua-Yun, X. I. A. O., Nan, L. I., \& Cong-Qiang, L. I. U. (2015). Source identification of sulfur in uncultivated surface soils from four Chinese provinces. Pedosphere, 25(1), 140-149.u,

Zhou, W., He, P., Li, S., \& Lin, B. (2005). Mineralization of organic sulfur in paddy soils under flooded conditions and its availability to plants. Geoderma, 125(1-2), 85-93. 